\title{
Pengelolaan Pemanenan dan Transportasi Kelapa Sawit (Elaeis guineensis Jacq.) di Bangun Bandar Estate, Sumatera Utara
}

\section{Harvest and Transportation Management of Palm Oil Fresh Fruit Bunch (Elaeis guineensis Jacq.) in Bangun Bandar Estate, North Sumatera}

\author{
Pangeran T. Anugrah dan Ade Wachjar*
}

Departemen Agronomi dan Hortikultura, Fakultas Pertanian, Institut Pertanian Bogor

(Bogor Agricultural University), Jl. Meranti, Kampus IPB Dramaga, Bogor 16680, Indonesia

Telp. \& Faks.62-251-8629353 e-mail agronipb@indo.net.id

*Penulis untuk korespondensi : wachjarade@yahoo.co.id

Published online Disetujui 14 Mei 2018 / Published online 21 Mei 2018

\begin{abstract}
The purpose of this research at Bangun Bandar Estate is to learn about technical and managerial aspect of oil palm plantation at the real condition. The other purpose of this research is to observe harvest and transportation of fresh fruit bunch to palm mill. The results of this observation shows that the harvesting management was good enough, as seen from the harvesting preparation, organization and actuation that well directed according to the standard. In harvesting activity things that should be evaluated were the harvester low awareness at the importance of wearing personal protective equipment. Evaluation was conducted to harvest area quality with a good result but still the unharvested fruit bunch, loose fruit and over pruning trees hadn't meet the standard. Fruit quality on fruit collecting point hadn't meet the standard as well but 83,2\% of the fruit was ripe and meet the qualification of minimum ripeness standard. Fresh fruit bunch transported well and approporiate capacity.
\end{abstract}

Keywords: fruit transportation, harvest management, harvesting quality, palm oil

\begin{abstract}
ABSTRAK
Kegiatan penelitian di Bangun Bandar Estate bertujuan untuk mempelajari aspek teknis dan manajemen perkebunan kelapa sawit pada keadaan yang sesungguhnya. Tujuan khusus dari penelitian ini adalah untuk mempelajari kegiatan panen dan transportasi tandan buah segar ke pabrik kelapa sawit. Manajemen panen yang dilakukan sudah baik yang ditunjukkan dengan adanya perencanaan, pengorganisasian, pelaksanaan dan pengawasan panen sesuai dengan standar. Pada kegiatan panen yang perlu dievaluasi adalah rendahnya tingkat kesadaran pemanen terhadap pentingnya penggunaan alat pelindung diri. Evaluasi dilakukan terhadap mutu hancak dengan hasil yang baik, meskipun pada beberapa hal masih memerlukan pengawasan intensif seperti buah matang tidak dipanen dan berondolan tinggal. Mutu buah di tempat pengumpulan hasil (TPH) belum seluruhnya memenuhi standar, tetapi buah matang yang dipanen sudah sesuai dengan standar kematangan yaitu $83,2 \%$. Pengangkutan buah telah dilakukan dengan baik dan sesuai dengan kapasitas unit angkut.
\end{abstract}

Kata kunci: kelapa sawit, kualitas panen, manajemen panen, transportasi buah 


\section{PENDAHULUAN}

Kelapa sawit (Elaeis guineensis Jacq.) merupakan salah satu tanaman industri yang cukup penting dan berperan dalam pembangunan nasional karena kelapa sawit adalah komoditas ekspor terbesar di Indonesia sehingga menjadi sumber devisa negara. Tahun 2010 volume ekspor minyak sawit mentah (CPO) mencapai 16.291.856 ton dengan nilai US\$ 13.468.966.000 meningkat pada tahun 2014 menjadi 20.557 .976 ton dengan nilai US\$ 15.838.850.000. Luas areal penanaman kelapa sawit juga mengalami peningkatan pada 3 bentuk usaha perkebunan di Indonesia. Tahun 2010 luas areal tanaman kelapa sawit perkebunan rakyat (PR) mencapai 3.387.257 ha meningkat pada tahun 2014 menjadi 4.551 .854 ha, luas areal tanaman kelapa sawit pada perkebunan besar nasional (PBN) tahun 2010 mencapai 631.520 ha, lalu meningkat pada tahun 2014 menjadi 748.272 ha, dan luas areal tanaman kelapa sawit perkebunan besar swasta (PBS) tahun 2010 mencapai 4.366.617 ha meningkat pada tahun 2014 menjadi 5.656.105 ha (Direktorat Jenderal Perkebunan, 2015).

Potensi pengusahaan kelapa sawit di Indonesia dinilai sangat baik karena Indonesia memiliki keunggulan yang dapat menjadikan industri komoditas kelapa sawit menjadi salah satu industri yang kompetitif di perdagangan dunia. Hal tersebut disebabkan Indonesia memiliki iklim tropika basah, pulau-pulau besar dan pulau-pulau kecil yang membentang di sekitar khatulistiwa Indonesia menyediakan areal yang cukup luas untuk pengembangan kelapa sawit (Maryani, 2012).

Salah satu tahapan dari kegiatan budidaya kelapa sawit adalah pemanenan, yang menjadi salah satu kunci penentu produktivitas kelapa sawit. Produktivitas kelapa sawit ditentukan oleh seberapa banyak kandungan minyak yang diperoleh dan seberapa baik mutu minyak yang dihasilkan. Hasil minyak yang diperoleh dipengaruhi oleh berbagai faktor, salah satu diantaranya adalah pelaksanaan panen kelapa sawit (Mukherjee, 2009).

Pemanenan tanaman kelapa sawit adalah pemotongan tandan buah segar dari pohon hingga pengangkutan ke pabrik. Pelaksanaan pemanenan meliputi: penentuan kriteria panen, kerapatan panen, rotasi panen, peramalan produksi penyediaan tenaga pemanen, organisasi panen, pengumpulan hasil, pengangkutan panen, dan pengawasan panen (Pusat Penelitian Kelapa Sawit, 2009).

Tandan buah segar (TBS) hasil pemanenan harus segera diangkut ke pabrik untuk diolah.
Buah yang tidak segera diolah akan menghasilkan minyak dengan kadar asam lemak bebas (ALB) yang tinggi. Peningkatan ALB dapat dicegah dengan pengolahan yang dilakukan paling lambat 8 jam setelah panen (Lubis, 2012).

\section{METODE PENELITIAN}

\section{Tempat dan Waktu}

Studi dilakukan di Bangun Bandar Estate yang berlokasi di Desa Tanjung Maria, Kecamatan Dolok Masihul, Kabupaten Serdang Bedagai, Medan, Sumatera Utara. Kegiatan penelitian dilakukan selama 4 bulan mulai Februari-Juni 2016.

\section{Pelaksanaan Penelitian}

Pelaksanaan penelitian di lapangan dilakukan dengan metode kerja secara langsung di lapangan produksi pada berbagai status karyawan, yaitu sebagai karyawan harian lepas (KHL) selama satu bulan, pendamping mandor selama satu bulan dan menjadi pendamping asisten afdeling selama dua bulan. Pada saat menjadi karyawan harian (KHT/KHL) pekerjaan yang dilakukan antara lain: melakukan persiapan bahan tanam, persiapan tanam dan penanaman, pemeliharaan tanaman, pengendalian gulma, pengendalian hama dengan sistem injeksi dan pengendalian insektisida, pembongkaran tanaman mati, pemupukan, mengisi jurnal harian yang diketahui pembimbing lapangan, mencatat prestasi kerja yang diperoleh mahasiswa dan karyawan dalam setiap kegiatan, dan membandingkan dengan norma kerja yang berlaku di perusahaan tempat penelitian.

Kegiatan pendamping mandor/mandor antara lain: membantu membuat perencanaan kebutuhan fisik dan biaya untuk pekerjaan yang akan dilaksanakan, membantu menentukan jumlah karyawan yang diperlukan beserta keperluan biaya operasional dari setiap kegiatan yang akan dilakukan, melakukan apel (pagi dan sore), dan mengawasi pemanenan meliputi kriteria panen, cara dan waktu panen, \% kehilangan hasil di lapangan dan selama transportasi, kerapatan panen, sistem panen, rotasi panen, dan analisis panen.

Kegiatan asisten afdeling antara lain: mempelajari kegiatan manajerial di tingkat afdeling, membantu penyusunan rencana kerja dan anggaran perusahaan (RKAP), membantu pembuatan laporan asisten, membantu pengelolaan dan pengawasan tenaga kerja yang menjadi tanggung jawabnya, dan melaksanakan analisis terhadap setiap kegiatan lapangan di tingkat afdeling. Kegiatan penelitian seperti 
kegiatan pengelolaan panen yang dilakukan antara lain: persiapan panen, pelaksanaan panen, perhitungan basis dan premi panen, pengawasan dan denda panen, organisasi panen, administrasi panen, serta transportasi panen.

\section{Pengamatan dan Pengumpulan Data}

Pengumpulan data dan informasi penelitian dilakukan dengan metode langsung dan tidak langsung. Data yang dikumpulkan meliputi data primer dan data sekunder. Data primer merupakan informasi yang diperoleh secara langsung melalui pengamatan penulis di lapangan meliputi kriteria matang panen dan sistem panen. Pada kriteria matang panen terdapat peubah yang diamati yaitu meliputi kebutuhan tenaga panen, angka kerapatan panen (AKP), taksasi panen harian, dan transportasi panen. Data sekunder yang diperoleh dari kebun meliputi keadaan tanah dan iklim.

\section{Kebutuhan Tenaga Panen}

Pengamatan kebutuhan tenaga panen harian dilakukan berdasarkan taksasi produksi harian.Kebutuhan tenaga panen harian diketahui dengan rumus sebagai berikut:

$$
\mathrm{T}=\frac{\mathrm{A} \times \mathrm{C} \times \mathrm{D} \times \mathrm{E}}{\mathrm{B}}
$$

Keterangan :

$\mathrm{T}=$ Jumlah tenaga kerja pemanen (HK)

$\mathrm{A}=$ Luas kavel atau kebun yang dipanen setiap hari (ha)

$\mathrm{B}=$ Kapasitas panen (kg/orang/hari)

$\mathrm{C}=$ Kerapatan panen $(\%)$

$\mathrm{D}=$ Rata - rata bobot tandan $(\mathrm{kg})$

$\mathrm{E}=$ Jumlah tanaman per ha

\section{Angka Kerapatan Panen (AKP)}

Kerapatan panen merupakan salah satu parameter yang sangat penting dalam penentuan taksasi produksi untuk keesokan harinya. Kerapatan panen dapat diketahui melalui taksasi produksi yang ditentukan.

Kerapatan panen

$$
\begin{aligned}
& =\frac{\text { jumlah buah matang }}{\text { jumlah pohon yang diamati }} \\
& \times 100 \%
\end{aligned}
$$

\section{Peramalan Produksi Harian (Taksasi Panen Harian)}

Perhitungan produksi harian diperoleh dari data presentase AKP sebelumnya yang diolah dengan rumus:

\footnotetext{
Taksasi panen $=\% \mathrm{AKP} \times$ Jumlah pohon produktif $\times$ Bobot rata - rata tandan
}

\section{Analisis Data dan Informasi}

Data yang diperoleh baik data primer maupun data sekunder dianalisis secara deskriptif dan kuantitatif dengan perhitungan-perhitungan statistik. Hasil pengolahan data disajikan dalam bentuk tabel untuk memudahkan pembahasan. Analisis kuantitatif adalah analisis data secara kuantitatif dan dilakukan perhitunganperhitungan secara matematis dengan menggunakan pengukuran rata-rata, persentase dan pendekatan statistik sederhana lainnya yang pada akhirnya akan menghasilkan kesimpulan melalui metode penarikan kesimpulan induktif.

\section{Keadaan Iklim dan Tanah}

Topografi lahan Bangun Bandar Estate meliputi lembahan, datar, hingga bergelombang dengan ketinggian 18-51 m diatas permukaan laut (dpl). Bangun Bandar Estate memiliki jumlah rata-rata curah hujan tahunan sebesar 2.294,6 mm, jumlah rata-rata bulan basah sebanyak 9 bulan dan bulan kering sebanyak 2 bulan, jumlah rata-rata hari hujan sebesar 131 hari dengan kisaran suhu $24-28{ }^{\circ} \mathrm{C}$ dan tipe iklim B (agak basah). Jenis tanah di Bangun Bandar Estate didominasi oleh tanah Alluvial dan Podzolik Merah Kuning 60-70\% dan sebagian kecil tanah gambut.

\section{HASIL DAN PEMBAHASAN}

Pekerjaan panen yang baik menghasilkan produksi yang tinggi dengan biaya yang minimum. Panen yang baik dilakukan dengan memperkecil potensi losses (kehilangan) sehingga dapat meningkatkan efisiensi panen. Manajemen panen dilakukan untuk meningkatkan efisiensi panen tersebut melalui perencanaan, pelaksanaan, evaluasi kegiatan panen hingga transportasi tandan buah segar (TBS) menuju pabrik.

\section{Persiapan Panen}

Sebelum melakukan panen terdapat persiapan panen yang perlu dilakukan untuk memaksimalkan potensi produksi, meminimalkan loses dan meningkatkan efisiensi. Hal yang perlu diperhatikan dalam kegiatan persiapan panen meliputi penghitungan angka kerapatan serta perkiraan produksi, menghitung tenaga panen yang dibutuhkan, menentukan hancak pemanen dan mengatur pusingan serta rotasi panen. Persiapan panen di Afdeling I Bangun Bandar Estate telah dilakukan dengan baik di lapangan.

Peramalan Angka Kerapatan dan Produksi. Peramalan angka kerapatan dan taksasi produksi 
merupakan hal pertama yang dilakukan sebelum melaksanakan panen. Melalui peramalan angka kerapatan panen, asisten afdeling dapat mengetahui estimasi produksi esok hari dan dapat menyesuaikan dengan produksi per hari yang ingin dicapai. Ketika kerapatan panen rendah, dapat dilakukan panen lebih dari satu seksi pada hari tersebut untuk tetap mengejar target produksi harian. Taksasi produksi yang dilakukan di Afdeling I Bangun Bandar Estate melibatkan seluruh mandor panen dan mandor 1. Mandor panen dan mandor 1 mengecek masing-masing kerapatan untuk satu blok. Pengambilan lokasi sampel dilakukan secara acak, umumnya masingmasing mandor mengambil sampel sebanyak 3 pasar rintis. Berdasarkan hasil pengamatan, varian taksasi harian berkisar antara $0,14 \%$ hingga $0,94 \%$. Hasil taksasi menggambarkan produksi panen aktual dengan baik.

Taksasi yang produksi luas panen rencana harus dimaksimalkan sesuai dengan luas panen aktual yang ditaksasikan sebelumnya, sehingga varian produksi hasil taksasi dengan aktual cukup tinggi. Hal tersebut juga dilakukan dengan menyejajarkan pemanen agar dapat mulai dan selesai pada blok yang sama pada waktu bersamaan, sehingga pada pelaporan janjang yang seharusnya dihitung pada seksi panen hari sebelumnya masuk pada pelaporan janjang pada panen hari tersebut. Pemanen bekerja sama dalam menyelesaikan hancaknya sehingga dapat selesai secara bersamaan. Sistem ini telah digunakan di Afdeling I Bangun Bandar Estate, tetapi masih belum berjalan dengan sempurna. Mutu buah panen harus sesuai dengan kriteria kematangan sehingga tidak menyebabkan tingginya varian.

Keadaan ini dapat diantisipasi dengan penetapan sanksi dan denda panen terhadap buah yang dipanen tidak sesuai standar kematangan yang berlaku. Terdapat kendala yang terjadi di lapangan, yaitu kurang representatifnya hancak yang menjadi sampel taksasi. Kurang representatifnya hancak dapat disebabkan oleh jalurnya yang sulit dilewati, banyaknya tanaman mati ataupun tanaman sisipan pada hancak tersebut. Hal ini dapat diatasi dengan mengambil hancak sampel lain untuk menambah keakuratan data taksasi.

Kebutuhan Tenaga Pemanen. Tenaga pemanenan memegang peranan penting dalam kegiatan panen. Tenaga pemanen menentukan kualitas buah yang dihasilkan. Untuk mendapatkan hasil panen yang optimal dan efisien perlu dilakukan manajemen yang baik terhadap tenaga kerja pemanen. Salah satu cara manajemen yang paling sederhana adalah dengan memenuhi jumlah tenaga pemanen sesuai dengan kebutuhan. Perusahaan yang mengikuti SOP dengan norma kerja pemanen sebesar 2-3 ha/HK, maka Afdeling I Bangun Bandar Estate membutuhkan tenaga pemanen sebanyak 38 orang. Jumlah tenaga pemanen yang tersedia di Afdeling I Bangun Bandar Estate sebanyak 37 orang untuk luasan tersebut. Afdeling I Bangun Bandar Estate dapat menjalankan panen dengan baik meskipun dalam kondisi kekurangan tenaga pemanen. Kekurangan tenaga pemanen saat panen puncak dapat ditutupi dengan menggunakan sistem kerja potong buah dimana terdapat satu orang karyawan yang bertugas untuk memotong buah, memotong pelepah dan mengangkut buah ke TPH serta satu orang karyawan yang bertugas untuk mengutip berondolan. Karyawan pengutip berondolan biasanya berasal dari tenaga karyawan harian lepas (KHL). Sistem seperti ini memungkinkan tenaga potong buah untuk mengeluarkan buah lebih cepat sehingga semua hancaknya dapat terpanen dengan baik.

Hancak panen. Hancak panen di Afdeling I Bangun Bandar Estate menggunakan sistem hancak giring tetap. Hancak giring tetap bertujuan untuk memudahkan pengontrolan terhadap kualitas panen karyawan, selain itu pemanen akan merasa bertanggung jawab terhadap hancaknya. Sistem hancak giring tetap digunakan agar mandor dapat mengakomodasi pemanen sesuai dengan hancaknya. Dengan sistem hancak giring tetap, mandor dapat menggiring pemanennya untuk membantu menyelesaikan hancak milik pemanen tersebut. Tidak seperti hancak giring tetap murni, dimana pemanen hanya memanen pada hancak tetap miliknya. Banyak faktor yang mempengaruhi pengancakan tenaga panen, tetapi secara teknis di lapangan pembagian hancak pemanen dilakukan hanya dengan menghitung jumlah baris tiap blok panen pada satu seksi yang dibagi sesuai jumlah pemanen. Hasil pembagian hancak tersebut harus adil dan merata sehingga setiap pemanen memiliki luasan hancak yang sama dan mendapatkan kesempatan untuk mencapai output panen yang sama.

\section{Rotasi dan Pusingan Panen}

Rotasi dan pusingan panen di Afdeling I Bangun Bandar Estate memiliki selang waktu antara satu seksi panen dengan kegiatan seksi panen berikutnya. Rotasi panen berkisar antara 3,5 - 4,5 kali per bulan. Pembagian seksi yang diterapkan oleh Afdeling I Bangun Bandar Estate adalah 6 seksi panen dalam satu minggu, mulai dari seksi A pada hari Senin hingga seksi F pada hari Sabtu. Pembagian seksi panen harus didasari 
oleh perhitungan bahwa satu seksi harus selesai dipanen dalam satu hari, perpindahan hancak pemanen harus mudah sehingga pengontrolan oleh asisten dan mandor dapat dilakukan dengan baik.

Pembagian seksi panen yang baik memudahkan transportasi tandan buah segar (TBS) dari TPH menuju ke PKS dan pusingan panen yang baik mengindikasikan suatu efisiensi panen, serta memberikan kesempatan pemanen mendapatkan basis borong dan memudahkan pemanen dalam mematuhi aturan panen dengan baik. Pembagian seksi panen dilakukan dengan pembagian rata apabila potensi produksi tiap blok relatif sama. Pusingan panen standar yang ditetapkan perusahaan adalah 6/7. Pusingan yang terlalu rendah akan menyebabkan banyaknya buah mentah yang dipanen oleh pemanen, sedangkan pusingan yang terlalu tinggi dapat menurunkan produktivitas pemanen karena banyaknya waktu yang tersita untuk mengutip berondolan. Pusingan normal dengan pembagian hancak yang baik dapat menghasilkan TBS dengan kualitas baik dengan kadar ekstrasi minyak tinggi dan kandungan asam lemak bebas yang rendah. Pusingan normal hanya dapat dicapai apabila pemanen menyelesaikan hancaknya sesuai dengan rencana panen.

Pengamatan pusingan panen terhadap pencapaian produksi di Afdeling 1 Bangun Bandar Estate yang dilakukan pada bulan Maret hingga Mei, menunjukkan bahwa produksi pada bulan April dengan persentase pusingan normal tertinggi yaitu $86 \%$ memiliki pencapaian produksi tertinggi pula yaitu $83,3 \%$ dibandingkan dengan pencapaian bulan Maret dan Mei. Persentase pusingan di atas normal pada bulan Maret sebesar $82,5 \%$ dan Mei sebesar $84 \%$ tergolong besar. Besarnya persentase pusingan di atas normal ini menggambarkan sering dilakukannya panen pada pusingan tinggi. Tingginya pusingan ini disebabkan oleh hari libur yang tidak diantisipasi dengan baik, hal tersebut dapat juga disebabkan oleh banyaknya karyawan yang tidak bekerja, hari libur dan hujan pada jam kerja. Pusingan yang tinggi dapat dikejar dengan memperpendek pusingan normal dan pusingan pendek sehingga terdapat waktu yang cukup untuk memotong pusingan panjang.

\section{Pelaksanaan Panen}

Alat Panen. Alat panen yang digunakan pemanen di Afdeling 1 Bangun Bandar Estate mayoritas diberikan oleh perusahaan kepada pemanen. Alat yang digunakan dalam kegiatan panen adalah dodos, egrek, angkong, gancu, kapak dan tojok. Menurut SOP perusahaan dodos digunakan untuk panen pada tanaman sawit yang berumur 5-8 tahun, sedangkan egrek digunakan untuk panen pada tanaman sawit yang berumur 9 tahun ke atas. Dodos digunakan untuk panen tanaman dengan ketinggian hingga 6 meter, sedangkan egrek biasa digunakan untuk panen pada tanaman dengan ketinggian lebih dari 6 meter. Afdeling 1 Bangun Bandar Estate tidak semua blok panen menggunakan egrek, mayoritas blok masih menggunakan dodos untuk panen. Buah yang telah diturunkan wajib dipotong pada bagian tangkai dan bagian parthenocarpy, lalu dibuang ke gawangan mati. Tangkai dan bagian parthenocarpy ini dipotong menggunakan kapak atau dodos. Penggunaan dodos untuk memotong tangkai buah dan bagian parthenocarpy dapat membuat dodos cepat rusak sehingga tidak dibenarkan penggunaannya. Buah yang telah dipotong siap untuk dinaikkan kedalam angkong menggunakan gancu.

Kondisi di lapangan kadang-kadang jalur atau hancak pemanen tidak bisa dilewati oleh angkong sehingga buah harus dievakuasi secara manual menggunakan karung. Buah yang telah diangkut ke TPH selanjutnya disusun dengan rapi menggunakan gancu. Berondolan yang telah dikutip harus menggunakan karung sebagai alas untuk mencegah kontaminasi dan memudahkan anggota bongkar muat untuk menaikkannya ke dalam dump truck. Karung yang digunakan biasanya berasal dari karung bekas pupuk ataupun terpal yang dijahit. Setelah semua buah dikeluarkan, buah dinaikkan ke dalam dump truck menggunakan tojok. Alat panen yang baik dapat menunjang kelancaran panen. Kendala yang sering ditemui adalah tumpulnya dodos yang digunakan, ban angkong yang bocor dan karung yang tertinggal. Kendala ini dapat menghambat pekerjaan panen. Untuk mengantisipasi hal tersebut pemanen seharusnya sudah membawa dan mengecek peralatannya saat apel pagi.

Alat Pelindung Diri. Perusahaan berkewajiban untuk melindungi pekerjanya dari kecelakaan kerja. Alat pelindung diri (APD) merupakan salah satu bentuk perlindungan tersebut. Para pemanen rawan terhadap kecelakaan kerja, sehingga harus senantiasa menggunakan APD. Berdasarkan pengamatan ada tiga jenis APD yang harus dikenakan oleh pemanen yaitu sepatu boot, helm dan kacamata. Sepatu boot dan helm disediakan oleh perusahaan tetapi kacamata belum terealisasikan pengadaannya. Pengamatan dilakukan terhadap seluruh pemanen dengan ulangan berupa kemandoran. Persentase penggunaan sepatu boot mencapai $100 \%$ tetapi penggunaan helm hanya mencapai $46,6 \%$. Hal 
tersebut menggambarkan rendahnya kesadaran pemanen terhadap potensi kecelakaan kerja. Pengawasan terhadap penggunaan APD pemanen juga belum berjalan dengan baik. Pengawasan seharusnya dilakukan oleh mandor panen saat apel pagi. Dari hasil wawancara terhadap pemanen diketahui alasan mereka tidak menggunakan helm disebabkan oleh perasaan tidak nyaman ketika menggunakannya saat panen bahkan menyebabkan keterbatasan gerak dari pemanen. Solusi terhadap masalah tersebut adalah dengan memberikan penyuluhan mengenai pentingnya penggunaan APD ketika bekerja untuk menghindari kecelakaan kerja. Selain itu, dibutuhkan komitmen dari para mandor untuk memantau penggunaan APD di lapangan. Belum ada solusi lain dari perusahaan untuk menggantikan penggunaan APD ini. Pengadaan kacamata juga perlu dilakukan, APD lengkap tidak hanya dibutuhkan oleh tenaga pemupuk ataupun pengendalian gulma kimia saja tetapi pemanen juga rentan terhadap kecelakaan kerja.

Tabel 1. Pengamatan persentase penggunaan APD pada tiap kemandoran

\begin{tabular}{|c|c|c|c|c|}
\hline \multirow{2}{*}{ Kemandoran } & \multirow{2}{*}{$\begin{array}{l}\text { Jumlah pemanen } \\
\text { (orang) }\end{array}$} & \multicolumn{3}{|c|}{ Pemakaian APD } \\
\hline & & Sepatu Boot (\%) & Helm $(\%)$ & Kacamata (\%) \\
\hline $\mathrm{A}$ & 11 & 100 & 42 & - \\
\hline B & 14 & 100 & 50 & - \\
\hline $\mathrm{C}$ & 12 & 100 & 48 & - \\
\hline Rata-rata & & 100 & 46,6 & - \\
\hline
\end{tabular}

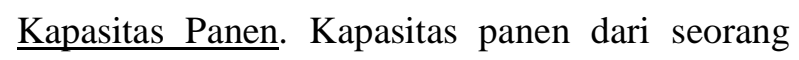
pemanen menggambarkan produktivitasnya per hari. Kapasitas panen sangat berpengaruh terhadap produksi. Pengamatan dilakukan terhadap 3 pemanen dari tiap kemandoran dalam satu rotasi panen. Basis borong yang ditetapkan perusahaan yaitu 150 janjang/HK pada hari Senin sampai Sabtu kecuali hari jumat dengan basis borong 125 janjang/HK.

Tabel 2. Pengamatan kapasitas pemanen dalam satu rotasi panen Afdeling I Bangun

\begin{tabular}{cccccc}
\hline \multirow{2}{*}{ Kemandoran } & \multicolumn{2}{c}{ Rata-rata kapasitas pemanen (janjang/HK) } & Total & Rata-rata \\
& Umur $<20$ tahun & Umur 20-30 tahun & Umur $>30$ tahun & $\begin{array}{c}\text { TBS } \\
\text { (janjang) }\end{array}$ & $\begin{array}{c}\text { TBS } \\
\text { (janjang/HK) }\end{array}$ \\
\hline A & 140,4 & 145,1 & 145,6 & 862 & 143,6 \\
B & 153,6 & 140,6 & 134,8 & 857,9 & 142,8 \\
C & 146,8 & 136,3 & 145,2 & 856,4 & 142,7 \\
Rata-rata & 146,9 & 140,6 & 141,8 & 858,8 & 143,0 \\
Standar Basis & 150 & 150 & 150 & 900 & 145 \\
\hline
\end{tabular}

Uji-t student untuk mengetahui perbedaan rata-rata kapasitas pemanen pada kelompok usia dan pusingan panen yang berbeda. Rata-rata kapasitas panen untuk usia 20-30 tahun mencapai 140,6 janjang/HK, sedangkan untuk usia 30 tahun ke atas kapasitas panennya hanya 141,8 janjang/HK. Setelah dilakukan uji t-student pada taraf 5\% diketahui bahwa nilai rata-rata kapasitas panen antara usia 20- 30 tahun dan 30 tahun

Tabel 3. Hasil uji-t student kapasitas pemanen pada pusingan 6/7

$\left.\begin{array}{cl}\hline \text { Pusingan panen } & \text { Rata-rata kapasitas panen(janjang/HK) } \\ \hline 6 / 7 & 146,9 \\ 6 / 7 & 140,6 \\ 6 / 7 & 141,8\end{array}\right]$ tn $\}_{* *}^{*}$

\section{Evaluasi Panen}

Mutu Hancak. Hancak panen merupakan tanggung jawab seorang pemanen. Pemanen wajib keatas tidak berbeda nyata. Uji-t student berikutnya dilakukan pada pusingan yang sama. Pusingan yang diuji adalah pusingan 6 hari. Ratarata kapasitas panen pada tiap pusingan 6 hari adalah 146,9 janjang/HK, 140,6 janjang/HK dan 141,8 janjang/HK. Hasil uji-t student pada taraf $5 \%$ menunjukkan bahwa tidak terdapat perbedaan nyata pada masing-masing kapasitas panen 6 hari. seluruh berondolan serta mengutipnya hingga 
bersih dan mengeluarkan seluruh janjang yang telah dipanen dan berondolannya ke TPH. Hancak panen terutama piringan dan pasar rintis harus selalu terjaga dari janjang maupun berondolan tertinggal. Disamping itu, pemanen harus turut menjaga jumlah pelepah tanaman sesuai dengan ketentuan. Cara termudah untuk menentukan jumlah pelepah ideal adalah dengan jumlah songgo. Jumlah songgo menggambarkan jumlah pelepah yang menyangga buah. Pelepah di tanaman dengan songgo $\mathrm{di}$ atas standar dikategorikan sebagai tanaman under pruning sedangkan tanaman dengan jumlah songgo dibawah standar dikategorikan tanaman over pruning. Pemeriksaan terhadap hancak panen dilakukan oleh mandor panen, mandor 1 , asisten, manajer dan juga mandor recolte. Pemeriksaan dilakukan pada hancak yang telah dipanen. Pengamatan dilakukan terhadap 5 pemanen pada tiap kemandoran di Afdeling 1 Bangun Bandar Estate, luas sampel yaitu 2 pasar rintis per pemanen. Penghitungan standar mutu hancak menggunakan kalibrasi luas per hektar sehingga jumlah buah matang tidak dipanen dan berondolan tinggal harus dihitung ke dalam satuan janjang/ha ataupun butir/ha. Standar mutu hancak yang digunakan ditetapkan oleh mandor recolte yaitu 2 butir berondolan tinggal per hektar, tidak boleh ditemukan buah matang tidak dipanen dalam hancak panen dan juga tidak diperbolehkan tanaman over maupun under pruning. Berdasarkan pengamatan janjang matang tidak dipanen dalam hancak yaitu sebanyak 0 janjang/ha. Rata-rata berondolan yang tinggal yaitu 0,6 butir/ha. Tidak ditemukan buah matang yang tidak terpanen. Tidak ditemukan tanaman dengan kondisi under pruning tetapi $1 \%$ dari jumlah tanaman total yang diperiksa dalam kondisi over pruning. Untuk kualitas hancak sudah sesuai standar dan kondisinya secara keseluruhan sudah cukup bersih. Buah matang dan berondolan tinggal, murni disebabkan oleh ketidaktelitian pemanen tetapi tetap harus ada sanksi yang ditetapkan.

Mutu Buah. Pemanenan yang baik harus memperhatikan aspek mutu buah pada tandan buah segar (TBS) yang dipanen karena hal itu dapat dijadikan indikator untuk mengetahui kulitas pekerjaan pemanen, buah harus dipanen sebelum lewat matang untuk menjaga asam lemak tetap rendah, tetapi juga tidak dalam kondisi kurang matang untuk bisa memaksimalkan produksi minyak. Salah satu cara mendapatkan mutu buah dengan kriteria tersebut adalah dengan memperketat pengawasan terhadap mutu buah. Setelah dikeluarkan oleh pemanen, buah akan di grading oleh kerani buah sesuai dengan kriteria yang ditetapkan. Mutu buah yang tidak sesuai dengan standar tidak dipengaruhi oleh pusingan karena pemanenan dilakukan pada hari panen dengan pusingan normal. Blok yang dilewati pemanen tidak memiliki masalah dan terlihat terawat dengan baik, blok dengan akses buruk memiliki keadaan sulit untuk dilewati oleh pemanen umumnya karena topografi lahan dan tanah yang licin karena terkena air hujan. Salah satu upaya yang dilakukan adalah dengan membangun parit untuk mengalirkan air hujan dan memantau ketinggian air agar tidak melebihi batas parit dan meluap masuk ke dalam blok.

Transportasi Panen. Pekerjaan terakhir dalam kegiatan pemanenan adalah transportasi buah hingga ke PKS. Kegiatan transportasi ini sangat penting sehingga kelancarannya harus sangat diperhatikan. Pengangkutan buah ke pabrik harus bersamaan dengan hari panen karena kadar ALB yang akan terus meningkat seiring waktu. Selain itu, ada beberapa hal yang menjadi sasaran kelancaran transportasi buah, yaitu kelancaran pengolahan di pabrik dan biaya transportasi TBS yang minimal. Faktor utama kelancaran transport adalah kondisi dan perawatan jalan. Transportasi panen umumnya terhambat bukan disebabkan oleh kurangnya alat angkut karena kondisi jalan yang tidak memadai. Pengangkutan buah harus diperhatikan bahwa jumlah janjang yang diangkut tidak boleh melebihi kapasitas angkut. Apabila melebihi kapasitas maka dapat mengakibatkan rusaknya alat angkut dan jalan.

Mekanisme pengangkutan TBS ke PKS di Afdeling 1 Bangun Bandar Estate dimulai pada pukul 09.00 dan trip pertama sudah masuk ke PKS mulai pukul 11.00 sedangkan trip terakhir pada pukul 16.00. Dalam satu kendaraan angkut buah terdapat satu orang supir dan 3 orang tenaga bongkar muat. Disamping itu, asisten dan mador panen, serta kerani buah harus selalu memantau kegiatan transport buah. Kegiatan transportasi panen diakomodir oleh bagian transportasi produksi. Tujuan adanya bagian pengelolaan transportasi perusahaan adalah untuk meminimalkan biaya angkut, pengaturan kerja lebih cepat, meminimalisir loses pada tahap transport panen serta untuk kelancaran operasional kebun.

Bagian transportasi produksi mengatur segala jenis transportasi di kebun, alokasi kendaraan dan alat berat, pemeliharaan dan perbaikan alat berat, menyediakan sparepart dan peralatan pendukung serta membuat dan memelihara jalan. Kendaraan angkut buah yang digunakan di Afdeling 1 Bangun Bandar Estate 
yaitu dump truck. Untuk kegiatan panen dioperasikan 2 unit dump truck pada tiap afdeling.

Kapasitas maksimal dari dump truck adalah $6.500 \mathrm{~kg}$. Afdeling 1 Bangun Bandar Estate hanya memiliki satu pabrik pengolahan kelapa sawit (PKS) dengan jarak antara afdeling 1 Bangun Bandar Estate ke pabrik adalah $6 \mathrm{~km}$. Berdasarkan analisa kebutuhan truk tahun 2015, diketahui bahwa maksimal trip per hari untuk satu dump truk dari afdeling 1 ke pabrik adalah 4 kali dengan maksimal produktivitas unit per hari sebesar 25,9 ton.

Berdasarkan pengamatan, waktu muat rata-rata yang dibutuhkan adalah 89,6 menit, lebih cepat dari standar yaitu 120 menit dengan waktu tempuh rata-rata yang dibutuhkan adalah 33,3 menit lebih lambat dari standar yaitu 25 menit. Waktu muat yang lebih lambat dari standar diduga dipengaruhi oleh jumlah muatan yang telah melebihi standar kapasitas yaitu $6.500 \mathrm{~kg}$, akan tetapi perusahaan sendiri tidak menetapkan standar baku yang pasti.

Kendala yang dialami dalam transportasi panen adalah produktivitas unit transport kebun yang rendah, sering terjadinya waktu kosong penerimaan buah di PKS dan kondisi jalan yang kurang baik. Kendala tersebut muncul karena kondisi jalan produksi yang belum siap pada segala cuaca, buah yang tidak serentak keluar dan pemanfaatan waktu yang kurang efisien. Hal ini dapat dihindari dengan pengeluaran janjang panen sejak pagi agar kegiatan transport buah dapat dilakukan lebih awal, selain itu pengeluaran buah dari hancak harus dilakukan secara serentak agar lebih efisien dalam pengangkutan. Perawatan jalan secara berkala juga harus direncanakan.

\section{KESIMPULAN}

Manajemen panen dan transport di Afdeling 1 Bangun Bandar Estate telah dilakukan dengan baik, tetapi dalam beberapa hal belum memenuhi kriteria standar operasional perusahaan. Persiapan panen hasil taksasi harian yang dilakukan belum dapat memenuhi kriteria varian di bawah 5\% dan jumlah aktual tenaga panen masih di bawah kecukupan. Saat pelaksanaan panen kesadaran pemanen akan keselamatan kerja dengan pemakaian APD lengkap masih sangat kurang. Kapasitas pemanen tergolong tinggi dengan persentase pencapaian basis sebesar $95,4 \%$, selain itu diketahui bahwa rata-rata kapasitas pemanen tertinggi terdapat pada pusingan 6 hari. Kualitas hancak sangat bersih dan sudah mencapai standar yang ditetapkan dengan persentase buah matang di TPH sudah mencapai 83,2\%.

Tujuan penulis melaksanakan kegiatan penelitian telah tercapai. Kegiatan penelitian dapat menambah pengetahuan dan melatih keterampilan penulis dalam budidaya kelapa sawit baik secara teknis di lapangan maupun secara manajerial, terutama dalam kegiatan panen dan transport buah.

\section{DAFTAR PUSTAKA}

Direktorat Jenderal Perkebunan. 2015. Statistik Perkebunan Indonesia 2009-2012. Direktorat Jenderal Perkebunan, Departemen Pertanian. Jakarta.

Lubis, A. 2012. Kelapa Sawit (Elaeis guineensis Jacq.) di Indonesia. Pusat Penelitian Perkebunan Marihat - Bandar Kuala. Marihat Ulu. 435 hal.

Maryani, A. 2012. Pengaruh volume pemberian air terhadap pertumbuhan bibit kelapa sawit di pembibitan utama. Jurnal Agroekoteknologi 1 (2): 64-75.

Mukherjee, S. 2009. Health Effects of Palm Oil. J Hum Ecol 26 (3): 197-203.

Pusat Penelitian Kelapa Sawit. 2009. Budidaya Kelapa Sawit. Medan. 157 hal. 